Jurnal Review Pendidikan dan Pengajaran

http://journal.universitaspahlawan.ac.id/index.php/jrpp

Volume 3 Nomor 2, Desember 2020

P-2655-710X e-ISSN 2655-6022
Submitted : $16 / 12 / 2020$

Reviewed : 20/12/2020

Accepted : 26/12/2020

Published : $31 / 12 / 2020$
Karina Alya Rohmadi ${ }^{1}$ Lilia Indriani ${ }^{2}$

\section{An Analysis of Students' Inhibition Level on Synchronous Class Using Video Conferencing}

\begin{abstract}
The COVID-19 pandemic has successfully forced a global shutdown of several activities, including in educational sectors, and this has resulted a migration of universities with online learning as the educational media (Adedoyin \& Soykan, 2020). However, the writer noticed that students are less responsive toward the lecturer's words during the synchronous class using a videoconference. One of aspect that might create this situation is inhibition, which is sets of barricades to shield ones' ego (Brown, 2000) or a temperamental proclivity to reveal caution, anxiety, or restraint in reaction to unfamiliar surroundings, objects, and circumstances (Kagan et all, 1988). Therefore the writer want to find out whether if the decreased intensity of students' responsiveness is influenced by inhibition during the video conference classes. There were 33 students from Tidar University's English education department who participated in this study. The participants were received open-ended questionnaire adapted from Mohseni and Ameri (2010). The findings revealed that there are inhibition that students experienced during the learning process in IVC class. The most influencing factors are affective factors and the factors that come from classroom interaction, including the fear of language evaluation.
\end{abstract}

Keywords: COVID-19 Pandemic, Inhibition, Videoconference Class.

\title{
INTRODUCTION
}

According to the World Health Organization (2020), COVID-19 is the infectious sickness instigated by the coronavirus, SARS-CoV-2, which is a respiratory pathogen. It was exposed in the last months of 2019 in a wet market in Wuhan. The Director of WHO publicized the outburst as a pandemic due to the swift surge in the number of cases outside of China. Based on Oxford Learner's Dictionaries, a pandemic is a sickness that extends over an entire country or the whole world. Social distancing is a conscious increase in the physical space between people to control the dissemination of disease (Red Cross, 2020). This pandemic has enforced global physical interaction of industries, sports events, and school activity by insistent all institutions to drift to online platforms (Adedoyn \& Soykan, 2020).

Online learning is one of the functions of the internet which is intended to develop materials for educational tenacities, instructional distribution, and controlling of programs (Fry, 2001). It refers to a teaching and learning setting where: (1) the learner is at a remote distance from the instructor, (2) the learner employs technology to get the materials of learning, (3) there is a practice of technology to create interaction between the learners, instructor and their peers, and (4) some kind of funding is served to learners (Anderson, 2011). Hrastinski (2008) addresses two forms of online learning, those are asynchronous and synchronous e-learning. Asynchronous e-learning, commonly assisted by platforms like e-mail and discussion boards. It

\footnotetext{
${ }^{1}$ Pendidikan Bahasa Inggris, FKIP, Universitas Tidar karina.alya11@gmail.com

${ }^{2}$ Pendidikan Bahasa Inggris, FKIP, Universitas Tidar indriani@untidar.ac.id
} 
provides a connection among learners and with teachers, even when participants cannot be online simultaneously. Synchronous e-learning generally supported by media such as videoconference and chat, and support a real-time interaction between the participants (Hrastinski, 2008).

A videoconference class is preferred to fulfill the requests of face-to-face learning during this pandemic. Since it allows the connected users to share a visual and audio connection in real-time (Al-Samarraie, 2019). By using a videoconference as the platform, the students and lecturer are expected to experience more social interaction. It is also an attempt to avoid frustration by enabling students and lecturers to do a question and answer session simultaneously. Al-Samarrie (2019) states interactive videoconferencing (IVC) is the type of videoconferencing that empowers one-to-many interaction where the host delivers their material to the audiences in real-time. However, this kind of videoconferencing requires a stable environment of internet connection and advanced configuration to maintain the interaction between the participants.

During IVC classes in these pandemic times, the writer noticed that the students become less responsive toward the lecturer's question. The lecturer needs to repeat the question for few more time after waiting for the response before finally, one or two students give their answer. This situation differs from how the face-to-face or physical class would occur. The lecturer would not need to wait too long for a response in a classroom setting where they meet the students in the same room. This situation brings the writer to a question of whether it is caused by inhibition or not, and if it is, then what are the factors that appear in students' inhibition.

Inhibition is sets of barricades to shield ones' ego (Brown, 2000) or a temperamental proclivity to reveal caution, anxiety, or restraint in reaction to unfamiliar surroundings, objects, and circumstances (Kagan et all, 1988). According to Kurtus (2019), inhibition to speak happened simultaneously with the distress of making mistakes that becomes a reason for students being afraid of appearing injudicious in front of other people. Richard and Schmdt (2002) also consider inhibition as a negative factor that hinders students from their natural performance and makes them act in a reluctant, hesitant, or anxious way.

According to Mohseni and Ameri (2010), the source of attitude problems, including inhibition, can be categorized into four: (1) cognitive factors that cover skill and understanding about grammar, vocabulary, and pronunciation, (2) affective factors that consist of the absence of motivation, insecurity, self-confidence, self-respect, and language ego, (3) the factors that come from classroom interaction, "since a good relationship of classroom members is an important key to create an ideal teaching environment" (Humaera, 2015), (4) fear of language evaluation. Inhibition that comes together with affective factors will be more influential for the learning process compared to the inhibition caused by cognitive factors. The mental inhibition such as lack of self-confidence, learning motivation, anxiety, and shyness more inhibit students in showing off their personality even though they have comprehension in language skills such as vocabulary, pronunciation, and grammar.

Previous studies on students' inhibition have varied results. Abedini and Chalak (2017) reported that the most influential factor contributing to inhibition in speaking was negative evaluation from teachers followed by students' anxiety and confidence, and students' linguistic knowledge. The findings of Loan and Tuyen (2020) revealed that more factors related to students cause inhibition than those related to teachers. Most of the students point out teachers' teaching methods, ways of giving corrective feedback, and attitudes towards students' knowledge and ability as the factor that causing inhibition. Mohseni and Ameri (2010) 
identified the three most influencing factors are offense or insult from teacher or classmates, student's psychological, and factors that come from cultural and racial.

\section{METHODOLOGY}

This study employed qualitative descriptive research to complete the research's goals. Cresswell (2009) states that qualitative research is an approach for exploring and understanding the connotation of individuals or groups to social or human concerns. The participants were the students of English Education Department of Tidar University, Magelang. The criteria for the participant are students who were in their 5th semester and participated in online learning activities during the COVID-19 pandemic. At the end of the data collection process, 33 students are willing to complete the answer to the questionnaire. The 33 students come from both male and female with the age range from 19-23.

The study employed a questionnaire for qualitative data as the instruments for collecting data. According to Cohen et.al. (2013), questionnaire is a commonly used useful tool for accumulating survey data, and providing structured data. It often as a numerical data, and often being comparatively straight forward to analyze. Through the questionnaire, the researchers inspected the participants' inhibition experience during a videoconferencing class. It consists of 12 items regarding factors causing inhibition in speaking performance. The questionnaire was adapted from Mohseni and Ameri (2010) as listed below:

1. In using the foreign language in conversation or discussion during a videoconference class, I feel:

Hesitant / comfortable / confident / talkative /cooperative / shy / afraid

2. When meeting speaker of English I tend to avoid conversation / switch to my first language / just listen / find faults / employ body language instead / use affected language / use jargon /volunteer to speak

3. Comment on your feelings about studying English by videoconfere class

4. What is the best and the worst thing about your videoconferenced language class?

5. What aspects of English appeal to you the most?

6. Describe the steps you take when using English is whatever form.

7. How well do you know yourself? What kind of personality are you?

8. What are the social, cultural, or other barriers in your study procedure?

9. Why should we study a foreign language at all?

To broaden insight / To satisfy the ego / To look down on others / For work / For prestige / for humanitarian reasons

10. What is your feeling when a classmate performs fairly well? Admiration / Jealousy / Envy / Neutral/ Anger / Humility / Awakening

11. My performance in the front of others audience during a videoconference class: is facilitated / nervous/ is impeded / is not affected at all / is exaggerated

12. In a videoconference class, I am passive / feel responsible / want to show off / don't feel bonded

The researcher used Google Form to collect the data because it was easier to use and suitable during the pandemic era. Google form is a free survey tool which includes in Google's complete office suite. Google Forms lets the researcher collect information from the participants via personalized surveys by connecting the info to a spreadsheet and automatically record the answers. Then the researcher analyzes all 33 data of the questionnaire using the four statements above to get the result. 


\section{RESULTS AND DISCUSSION}

This chapter presents the research findings and discussion about the factors' that inhibit students to speak in IVC class. The researchers categorize the analyzed data gathered from the 12 items of the questionnaire's question adapted from Mohseni and Ameri (2010). The researcher groups the question into four categorize cognitive factors, affective factors, factors from classroom interaction, and factors from fear of language evaluation. Then, the researcher analyses all the results from 33 students as mentioned before.

Cognitive factors refer to features of a person that influence performance and learning. These factors involve cognitive functions like attention, memory, and reasoning (Danili \& Reid, 2006). As in speaking performance, the cognitive factors are including grammar, vocabulary, and pronunciation (Mohseni \& Ameri, 2010). These factors are inspected through question items number 6, and 11.

Question number 6, "describe the steps you take when using English in whatever form" questions the students on how they process the thought or idea inside their head until they convey it into English. Most of the answers claim that their speech naturally flowing out as they thought about the idea. Some claim that they think in their first language and translated into English, or they prepare what they are going to say by arranging the sentence first before delivering it orally.

It's just naturally flow from my brain to responds in English if someone talk to me with English language, but sometimes I prepare some words than translate it in my brain before giving responds. Meanwhile in writing, I use google translate to help me when I don't know the meaning of sentence or words.

Questionnaire, 25/11/2020 12:55:24

The steps when I take using English is, I try to string up words first in my mind, after that try to speak it.

\section{Constructing what matters I should make and express at first. \\ Questionnaire, 01/12/2020 13:44:41 \\ Questionnaire, 25/11/2020 13:37:15}

These answers show that students have enough vocabulary and grammar understanding to the point the words just flow out naturally, or they can prepare what they want to say just by translating it in their mind.

Questions number 11, "my performance in the front of other audiences during a videoconference class..." asks the students how they saw their performance in front of the audience. In this question, the students can choose one of the choices: "is facilitated", "nervous", "is impeded", "is not affected at all", and "is exaggerated". This question not only inspects students' cognitive aspects but also their affective aspects since their performance is not only influenced solely by their skills in cognitive but also the affective factors. The highest answer for this question is "nervous" which is $69.4 \%$ and followed by "is not affected at all" with $16.7 \%$ answer. It means that even though the students have adequate cognitive skills, their speaking performance is still inhibited by the affective factors which make them feel nervous.

The affective domain (Krathwohl et.al., 1973) includes the way in which we deal with matters emotionally, such as feelings, gratitude, passions, and attitudes. Based on Mohseni and Ameri (2010), affective factors that inhibit students to speak are motivation, insecurity, selfconfidence, self-respect, and language ego. The affective factors have more impact on students' improvement process. It is because these factors inhibit students from showing off their personality even though they have comprehension in language skills like what happens in the answer to question number 3 . The other question for affective factors is number 1, 2, 7, 5, and 9.

Question number 1, "in using the foreign language in conversation or discussion during a videoconference class, I feel," is revealing how confident the students are in using English during IVC class. The result, however, is also affected by the factors that come from class interaction, whether it is from the lecturer or their classmates. Since a good and supportive classroom more likely to harm students' affective domain. There are two answers with the highest number, those are "comfortable" and "afraid" with both percentages are $22.2 \%$. The 
result revealed that there are students who are comfortable using English in IVC class, yet there are more who also feels afraid to use the language. Affective factors like self-esteem, confidence, and language ego play a big role in this case. These factors are the factors that pushing the students to practice English or keeping them from practicing. Again, factors that come classroom also influence students' willingness in speaking English inside the class.

Question number 2, "when meeting speaker of English I tend to," inspects how the students will react in that situation. The choices for the question are "avoid conversation", "switch to my first language", "just listen", "find faults", "employ body language instead", "use affected language", "use jargon", and "volunteer to speak". The answer from this question are varied. Here is the result ordered from the highest to lowest: "just listen" (36.1\%), "volunteer to speak" (13.9\%), "avoid conversation" (25\%), "switch to my first language" $(8.3 \%)$, "use body language instead" (8.3\%), "use affected language" (5.6\%), "find faults" $(2.8 \%)$, and use jargon $(0.0 \%)$. The answer that avoids using English indicates a lack of confidence and language ego, as well as a lack of motivation to actually practice English. The answer where students use flawed English indicates that students have enough affective factors to push them to practice English even though their cognitive factors are still not maximal.

Question number 5 is asking the students what aspect that appeals the most to them. It is an open-ended question so it allows students to mention what they like the most about English freely. The answer can be their reason to start to learn English or the goals that they gain they want from learning English. The responses to this question fall into two categories: the answer that mentions language skills and the sociolinguistic aspects. The language skills answer consist of items such as speaking, pronunciation, grammar, speaking, and writing, while the sociolinguistic consist of answers like accent, culture, and interaction with people from different places. However, from 33 entries, only 24 students answer this question.

Question number 7 is "how well do you know yourself? What kind of personality are you?" This questions ask the students to describe their personality and reveal how they see themselves from their perspective. Most of the answers show positive attitude of explaining how they see themselves.

Hard worker, ambitious

Questionnaire, 25/11/2020 12:52:38

I know myself pretty well and I think I am an introverted person that loves comfortable and more concerned with feeling.

Questionnaire, 28/11/2020 4:47:23

I know me well, I am ambivert person and I like writing

Questionnaire, 03/12/2020 7:57:30

Other students are answering using their strengths and weakness while maintaining the positive attitude.

I think I know myself well enough, I am a person that don't like the rules, sometimes I do what I wanna do without thinking of the other person opinion, I'm easily touched by little things, I'm optimistic, I don't really like meddling in other people's problems, I'm a very private person, I do not like routine, sometimes I like challenges and I like freedom, but I am less organized and but sometimes I'm afraid to fail.

Questionnaire, 06/12/2020 10:19:55

Some give a neutral attitude answer by stating how their personality is in general.

I am flexible

Questionnaire, 25/11/2020 12:54:41

I'm an extrovert person

Questionnaire, 01/12/2020 13:20:14

However, few students answer with a negative attitude toward their perspective of their own.

I am a shy person and I am not really confident with my knowledge and my social

life. 
Questionnaire, 25/11/2020 13:29:14

These various answers reveal that the condition of affective factors of each student is widely varied. The affective factors work differently in each student. Those who answer with a positive attitude have a high level of self-esteem since they know their worth. They understand their strength and weakness so they know their value and not lower themselves. Meanwhile, those who give a negative attitude, more likely to have a problem coping with nervousness and anxiety, they also have an issue to get confident in themselves.

Question number 9 asks the students concerning their motivation for learning English. The question is "why should we study a foreign language at all?" and the choices for the answer are: "to broaden insight", "To satisfy the ego", "To look down on others", "For work", "For prestige", and "for humanitarian reasons". As a result of this question, 4 answers got chosen: "to broaden insight" (69.4\%), "for work" (13.9\%), "for humanitarian reasons" (11.1\%), and "for prestige" $(5.6 \%)$. Two of four of the results are integrative motivation, which are "to broaden insight" (69.4\%) and "for humanitarian reasons" (11.1\%). It moves learners to learn a language because of the positive attitudes toward the target language group and their intention to join together with the target language community. Then, the other two "for work" $(13.9 \%)$ and "for prestige" $(5.6 \%)$, are instrumental motivation which is learning a foreign language for work. Instrumental motivation is a motivation that drives learners to learn a language with a more useful purpose of the language such as applying for a well-paid job or achieving higher social status.

Many aspects come from classroom interaction that might trigger inhibition in students. A bad environment where bullying or discrimination happening would create a negative impact on the students. The size of the group learning can be a factor that inhibits students from speak up as well. How the students' and peers' relationship happens in a class also determines the inhibition of the students. The lecturer and student relationship have as big as the student-tostudent relationship does. Moreover, negative treatment from the lecturer such as punishment, favoritism, and discrimination contribute to a higher level of inhibition. Fear of language evaluation, likewise, can be resulted from negative chemistry between people in the class, both from the lecturer and students. Question number 3, 4, 10, and 12 are concerning the factors from the classroom and fear of evaluation as the factor causing inhibition.

Question numbers 3 and 4 are asking students for their perspectives on IVC class. Question number 3 asks what students feeling about studying in IVC class and question number 4 asks the students their view on the best and worst part of experiencing learning in IVC class. For the response of question number 3,51.5\% of students answer it with a negative perception, $30.3 \%$ of students have a positive perception of it, and $18.1 \%$ with a neutral answer. The answers to this question are related to question number 4 . In question number 4 , answers regarding the convenience of IVC are the most frequent answer for the best part of IVC class. Other answers on the best part of IVC are the ability to turn off the camera, the interaction with peers, and extended time to get ready to participate in the class. Then for the worst part of IVC class is the problem with internet connection followed by less time to practice, a problem in understanding material, and unsuitable teacher's teaching style.

The negative answers admit that they feel uncomfortable attending IVC class. The reasons are less or more the same with the answer for the worst part of IVC class in question number 4, with the main issue is being unable to understand the learning material. Few students also confess that they feel shy and afraid so that some of them choose to turn the camera off. 
Meanwhile, the students with positive answer say they feel comfortable because they feel less nervous and believe that IVC works better than learning activity through a chatting platform.

From these two question researchers believe that students' level in understanding the material influences their confidence during the class. If the students fail to understand the material, their anxiousness, nervousness, and inhibition level will be increasing which makes them feel uneasy or scared. Turning off the camera is one way for the students to avoid speaking up.

The best is I can turn off the camera when I speak, so I'm not shy if I can't pronounce well. The worst is I feel more nervous if speaks directly to the lecturer.

Questionnaire, 25/11/2020 12:55:24

The best thing is that I can express my thought without face to face directly which usually makes me nervous. The worst thing is when the class is not going well because of the connection or the lesson need direct practice.

Questionnaire, 28/11/2020 14:05:13

The absence of visuals, however, tone down a little bit the anxiety caused by the low rate of understanding. If the student doesn't need to show her or his face then they can avoid more impact of losing face when they make mistake, whether it is mispronunciation or giving a wrong answer. Furthermore, the fact that students avoiding to speak because they are scared of making mistake is indicating the presence of fear of language evaluation.

Question number 10 and 12 focused on students' perception of their peers and their engagement in the class. The question for number 10 is "what is your feeling when a classmate performs fairly well?" with the results are: "admiration" (52.8\%), "neutral" (25\%), "envy" (11.1\%), "jealousy" (5.6\%), and "humility" (5.6\%). The results of this question indicate that student's perception of their peers' success is generally positive. Half of the participants give positive answers toward the situation given, then a quarter of them choose to be neutral toward their peers' well performance. Only around $16.7 \%$ of the total answer who gives negative responses to their peers' achievement by feeling jealousy and envy. Last, the rest of the answer is feeling humility which means the students feeling ashamed about themselves of being not able to achieve the same level as their peers. Therefore, a student-to-student relationship between the students of the 5th semester in English Department of Tidar University doesn't seem to be the problem in causing inhibition during IVC class.

Then, question number 12 is "In a videoconference class, I" which is investigating how the students engage in the IVC classroom. The result is 50\% of the students have low engagement in the class and choosing to be passive, $16.7 \%$ confess that they do not feel a connection to other participants of IVC class, and $36,1 \%$ of the students feel responsible to be active during the class. Of course, aside from the factors that come from classroom interaction, students' engagement is also influenced by student's affective factors, like motivation. The high number of passive students can indicate a lack of motivation for the students to actually participate in the class. However, $16.7 \%$ of students who say don't feel connection among their peers also can be interpreted as a sign of bad chemistry between the people of the class. It also can be the reason why there are only $36,1 \%$ of the students who feel responsible while the rest stay passive during a class.

Aside from the four categories of the source of an attitude problem, according to Mohseni and Ameri (2010), there is an extra personal factor that causing an inhibition on students. This factor truly raise from a personal issues like ethnic, cultural problems such as language shock, culture shock, culture stress and anomie, vocational which are degree-oriented or money-driven 
impulse, sociological issue, etc. Question number 8 asks this extra personal factors that obstruct the students in their learning and developing process of using English. The question is, "what are the social, cultural, or other barriers in your study procedure?" It is an open-ended question so the students have the freedom to answer based on their experience.

Cultural conditions, cultural differences will affect perceptions, ways of thinking, as well as the language used by the individual concerned. So that in the implementation of cross-cultural communication often finds obstacles, for example differences in perceptions due to differences in language.

Questionnaire, 26/11/2020 9:01:27

I feel I don't have many chances to practice English speaking in daily life because people around me don't speak English.

Questionnaire, 27/11/2020 13:32:08

I think that the financial issues is one of the crucial barriers in my study procedure.

Questionnaire, 25/11/2020 13:37:15

Therefore, 14 from 33 entries mentions barriers related to the unsupportive environment whether it is because of the distraction of surrounding or because English is not normally used or accepted to be daily language in that environment. Next is a cultural difference between the use of English that being taught and how English is actually used in English-speaking countries. Some other answer also mentions the problem with financial.

\section{CONCLUSSION}

The study was conducted to find out whether there is an inhibition happening during IVC classes in COVID-19 pandemic education. Therefore, the researchers also want to explore the factors causing inhibition in students of $5^{\text {th }}$ semester of English Education Department of Tidar University. The study focused to the teaching-learning activity through interactive videoconference class during COVID-19 pandemic. The findings revealed that there are inhibition that students experienced during the learning process in IVC class. The most influencing factors are affective factors and the factors that come from classroom interaction, including the fear of language evaluation.

Based on the survey, 51.5\% of students have a negative perception on joining IVC class. The reason is because of the problem with internet connection followed by less time to practice, and a problem in understanding material. Turns out, students' level of understanding material have influences on their confidence during the class. If the students fail to understand the material, their anxiousness, nervousness, and inhibition level will be increasing which makes them feel uneasy or scared. This is why most of the students choose to turn their camera off and being less responsive and more passive. The absence of visuals also help students to cope with the anxiety caused by the low rate of understanding. If the student doesn't need to show her or his face then they can avoid more impact of losing face when they make mistake. Therefore, it can be said that fear of evaluation, likewise, have impact on increasing students' inhibition level in a class.

\section{REFERENCES}

Abedini, F., \& Chalak, A. (2017). Investigating the Inhibitive Factors in the Speaking of Iranian. Journal of Applied Linguistics and Language Research, 4(6), 82-97. http://www.jallr.com/index.php/JALLR/article/view/636

Adedoyin, O. B., \& Soykan, E. (2020). COVID-19 pandemic and online learning: The challenges and opportunities. Interactive Learning Environments, 1-13. https://doi.org/10.1080/10494820.2020.1813180 
Al-Samarraie, H. (2019). A scoping review of videoconferencing systems in higher education. The International Review of Research in Open and Distributed Learning, 20(3). https://doi.org/10.19173/irrodl.v20i4.4037

Anderson, T. (2011). The theory and practice of online learning (2nd ed.). Edmonton: Athabasca University Press.

Brown, H. D. (2000). Principles of language learning and teaching. Prentice Hall.

Cohen, L., Manion, L., \& Morrison, K. (2013). Research methods in education. Routledge.

Coronavirus. (2020, January 10). https://www.who.int/health-topics/coronavirus\#tab=tab_1

Creswell, J. W. (2009). Research design: Qualitative, quantitative, and mixed methods approaches. SAGE.

Danili, E., \& Reid, N. (2006). Cognitive factors that can potentially affect pupils' test performance. Chem. Educ. Res. Pract, 7(2), 64-83. https://doi.org/10.1039/b5rp90016f

Fry, K. (2001). E-learning markets and providers: Some issues and prospects. Education + Training, 43(4/5), 233-239. https://doi.org/10.1108/eum0000000005484

How to social distance during COVID-19. (2020, May 13). American Red Cross | Help Those Affected by Disasters. https://www.redcross.org/about-us/news-andevents/news/2020/coronavirus-what-social-distancingmeans.html\#: :text=If\%20you\%20must $\% 20$ go\%20in,shops\%20or\%20any $\% 20$ other $\% 20$ place

Hrastinski, S. (2008). Asynchronous and synchronous e-learning. Educause Quarterly, 31(4), 51-55. https://er.educause.edu/-/media/files/article-downloads/eqm0848.pdf

Humaera, I. (2015). INHIBITION IN SPEAKING PERFORMANCE. Journal of The Association for Arbic and English, 1(1), 31-50. http://dx.doi.org/10.31332/lkw.v1i1.379

Kagan, J., Reznick, J. S., Snidman, N., Gibbons, J., \& Johnson, M. O. (1988). Childhood derivatives of inhibition and lack of inhibition to the unfamiliar. Child Development, 59(6), 1580. https://doi.org/10.2307/1130672

Krathwohl, D. R., Bloom, B. S., \& Masia, B. B. (1973). Taxonomy of Educational Objectives, the Classification of Educational Goals. Handbook II: Affective Domain. New York: David McKay Co., Inc.

Kurtus, R. (2019, August 11). Overcome the fear of speaking to groups. School for Champions by Ron Kurtus - online lessons for those seeking success. https://www.school-forchampions.com/speaking/fear.htm\#.X5EkF9AzbIU

Mohseni, A., \& Ameri, A. (2010). Inhibition revisited in EFL learning/teaching. Journal of language and Translation, 1(1), 39-50. http://ttlt.azad.ac.ir/article_514727.html

Richards, J. C., \& Schmidt, R. (2002). Longman dictionary of applied linguistics and language. Harlow: Longman. 